\title{
A COMPREHENSIVE REVIEW ON SUPERSATURABLE SELF-NANOEMULSIFYING DRUG DELIVERY SYSTEM
}

\author{
MUTHADI RADHIKA REDDY ${ }^{1}$, KUMAR SHIVA GUBBIYAPPA ${ }^{2 *}$
}

${ }^{1}$ Department of Pharmaceutics,GITAM Institute of Pharmacy, GITAM University, Gandhi Nagar Campus, Rushikonda, Visakhapatnam, Andhra Pradesh, India. ${ }^{2}$ Department of Pharmaceutics, School of Pharmacy, GITAM Deemed to be University, Hyderabad, Telangana, India. Email: sgubbiya@gitam.edu

Received: 06 May 2021, Revised and Accepted: 24 June 2021

ABSTRACT

Lipid-based drug delivery systems are extensively reported in the literature for enhancing drug solubility, permeability, and bioavailability. Selfnanoemulsifying drug delivery systems (SNEDDS) are a superior strategy for enhancing solubility and bioavailability of poorly water-soluble compounds and the most prevailing and commercially viable oil-based approach for drugs that exhibit low dissolution rate and inadequate absorption. However, these formulations have few limitations that include in vivo drug precipitation, inferior in vitro in vivo correlation owing to unavailability of in vitro tests, handling issues of liquid formulation, and physicochemical instability of drugs. These limitations are overcome by potential systems such as supersaturable SNEDDS (S-SNEDDS) which are prepared by addition of precipitation inhibitors into formulated SNEDDS to maintain drug supersaturation post dispersion in gastrointestinal tract. These systems improve drug bioavailability and reduce the inconsistency of exposure. In addition, these formulations also help to overcome the drawbacks of liquid and capsule dosage forms. The S-SNEDDS provides an effective approach for improving the dissolution and bioavailability of anti-cancer agents. In this article, an attempt was made to present an overview of SNEDDS, S-SNEDDS, their mechanism, formulation excipients, recent advancements, advantages, and disadvantages of SNEDDS formulations. The article also focuses on reviewing the application of S-SNEDDS in enhancing the solubility and bioavailability of anti-cancer drugs in cancer therapy.

Keywords: Solubility, Supersaturable self-nanoemulsifying drug delivery systems, Nanotechnology, Precipitation inhibitors, Cancer.

(C) 2021 The Authors. Published by Innovare Academic Sciences Pvt Ltd. This is an open access article under the CC BY license (http://creativecommons.org/ licenses/by/4.0/) DOI: http://dx.doi.org/10.22159/ajpcr.2021v14i8.41987. Journal homepage: https://innovareacademics.in/journals/index.php/ajpcr

\section{INTRODUCTION}

Oral route for drug delivery represents more than $70 \%$ of total dosage forms utilized by humans, and this can be related to its convenient and acceptability as a mean for the administration of drug molecules to patients since it associates with a high rate of patient compliance in one hand and economic and flexible dosage design in others [1,2]. One of the most important prerequisite requirements of drug molecules to be available for systemic absorption is aqueous solubility since that is the nature of GIT fluid. Then, when the drug molecules become solubilized, it has to pass the biological membrane to reach the systemic circulation [3].

Food and Drug Administration (FDA) classifies drug molecules to belong to one of four categories based on their aqueous solubility and ability to pass through the biological membrane, termed as permeability. This classification system is called the Biopharmaceutical Classification System (BCS) $[4,5]$.

Drug molecules that belong to Class II have a problem in bioavailability mainly due to low aqueous solubility. In this class, the rate-limiting step is dissolution process and so choosing of suitable drug delivery, and appropriate additives are crucial to overcome this major obstacle and improve the fraction that will reach the systemic circulation [6].

Many approaches were developed to overcome this issue with a variable degree of success, from these approaches solid self-emulsifying drug delivery system (SSEDDS) is extensively tried.

SEDDS out of various strategies available to date, SEDDS belonging to lipid-based technique were proved to upsurge drug dissolution rate and assisted the formations of soluble drug phase. These formulations are filled into soft and hard gelatin capsules easily [7,8]. The selfemulsifying formulation is an isotropic blend of drug, lipids, surfactants, and co-solvent that generate superfine emulsion on agitation in the gastro intestinal (GI) tract [9]. The SEDDS are categorized into two types, namely, SMEDDS, and Self-nanoemulsifying drug delivery systems (SNEDDS), based on globule sizes formed on dispersion [10]. SMEDDS are formulations that produce a transparent microemulsion of oil-in-water or water-in-oil with a globule diameter $<250 \mathrm{~nm}$. SNEDDS possess a droplet size of $20-200 \mathrm{~nm}$ that is transparent [11]. SNEDDS is a competent, well-designed, and patient compliant technique for sparingly soluble drugs, as it enhances the solubility, dissolution patterns in the GI tract, increases permeability, and enhances absorption [12-14].

\section{SNEDDS MECHANISM OF ACTION}

The SNEDDS on administration, followed by gentle agitation arising from gastric movements, forms oil in-water nanoemulsion immediately and impulsively with particles of nanometric range $(<200 \mathrm{~nm})$. These nanoparticles comprising the drug that is previously dissolved in the oil phase provides a superior interfacial surface to facilitate dispersion into GI fluids [15]. This increased interfacial area enhances drug solubility and permeability by altering transport property [16]. Nanosize droplets experience rapid digestion followed by quicker absorption of the drug into the GI tract. SNEDDS dosages range between $25 \mathrm{mg}$ and $2 \mathrm{~g}$ [17]. These are effectively encapsulated as single dosage forms which provide greater stability, palatability, and patient acceptance [18-21]. They also possess higher drug loading capacity when compared to other lipidbased formulations.

\section{SELECTION OF APPROPRIATE DRUG CANDIDATES FOR SNEDDS FORMULATION}

The challenges faced by a formulator during the formulation of an oral dosage form are to solubilize the drug in the GI tract. SNEDDS improve the rate and scope of drug absorption. SNEDDS approach is applied for BCS Class II drugs that suffer from inferior water solubility and bioavailability [22]. Administration of these drugs in form of lipids enhances their bioavailability by bypassing the absorptive barrier of 
reduced water solubility and illustrate dissolution in GI by transferring to the bile-salt mixed micellar phase, through which absorption happens readily [23]. Properties of the drug, including water solubility, log P are not adequate to identify the suitability of lipid-based formulation, as they do not predict the in vivo effects [24]. In SNEDDS formulation, the free energy required for the formation of an emulsion is either little or positive or negative. Hence, emulsification happens impulsively. It is essential for the interfacial structure to illustrate no confrontation against surface shearing such that emulsification takes place. The ease of emulsification may be due to the simplicity of water penetration into a variety of liquid crystalline or gel phases on the droplet surface [25-29].

\section{EXCIPIENTS USED IN SNEDDS FORMULATION}

Oils

The oil is used in SNEDDS formulation for solubilizing the lipophilic drug and ease self-emulsification, to augment the amount of drug passing through the intestinal lymphatic system, thus, enhancing absorption. The long and medium-chain triglycerides (LCT and MCT) with varying saturations are employed. The edible oils are not chosen for SNEDDS formulation due to their inability to solubilize larger drug concentrations. Hydrolyzed vegetable oils are used due to the formation of superior emulsification systems with more surfactants accepted for oral administration. They put forward formulation and physiological recompense. New semi-synthetic medium chain compounds, known as amphiphilic compounds that possess surfactant characteristics, are substituting the oils in SNEDDS [30-34].

\section{Surfactants}

The orally acceptable surfactants are non-ionic that possess higher hydrophilic-lipophilic balance (HLB). Frequently employed emulsifiers, include ethoxylated polyglycolyzed glycerides and polyoxyethylene oleate. Natural emulsifiers are considered safer than synthetic versions but surfactants possess the incomplete self-emulsifying ability. Nonionic surfactants have lesser toxicity compared to ionic surfactants and direct to enhance permeability through the intestinal lumen [30-34].

\section{Co-surfactant}

The SNEDDS formulations require relatively higher concentrations $(>30 \% \mathrm{w} / \mathrm{w})$ of surfactants, which can be condensed by the addition of co-surfactant. These along with surfactants lower the interfacial tension to -ve value, where it expands to form fine droplets that are consequently adsorbed larger quantities of surfactant and surfactant/ co $\mathrm{T}$ surfactant till the interfacial tension turns + ve. This process is called "spontaneous emulsification." The addition of co-surfactants into SNEDDS is not obligatory for most non-ionic surfactants [41]. In SNEDDS, the co-surfactants with HLB values ranging between 10 and 14 are used. Hydrophilic co-surfactant is alcohol with mediumchain lengths, including hexanol, pentanol, and octanol that reduce interface between oil and water that facilitate impulsive microemulsion formation [42-45].

\section{ADVANCEMENTS IN SNEDDS}

\section{Supersaturated SNEDDS (S-SNEDDS)}

The extent of drug solubility in excipients used for SNEDDS formulation determines the dosage of drug loading. The solubilizing ability of SNEDDS is reduced due to a reduction in lipid content that leads to drug precipitation. Drugs that are highly soluble in surfactants or cosurfactant than lipophilic phase precipitate easily as the solvent ability of these excipients reduces with dilution. Hence, the majority of SNEDDs formulations contain drugs lower than equilibrium solubility. In one, the presence of large amounts of hydrophilic surfactants also facilitates drug precipitation. To overcome this drawback, S-SNEDDS comprising hydrophilic precipitation inhibitors (PIs) were studied [46,47]. These S-SNEDDS reduce precipitation of drugs in the GI tract by attaining a metastable saturated state. This mechanism involves the assimilation of polymeric PIs (PPIs) that are water-soluble, resulting in prolonged precipitation time in comparison to mean absorption time. Polyvinyl pyrrolidone, hydroxypropyl methylcellulose (MC), sodium carboxymethyl cellulose, and MC polymers are some commonly used PPIs. Few drugs precipitate in an amorphous state and demonstrate prominently fast dissolution post precipitation when evaluated in vitro. This indicates that the precipitation of such drugs enhances the bioavailability. Few S-SNEDDS were prepared without the use of PPIs by subjecting the formulations to an alternate "heating and cooling cycle" $[48,49]$. S-SNEDDS enhance the stability, concentration versus time profile, drug release rate, the scope of absorption, drug bioavailability, half-life, and feat of hydrophobic and less lipophilic drugs [50,51]. Recently S-SNEDDS for simvastatin ezetimibe, silymarin halofantrine, trans-resveratrol, hydrocortisone, and paclitaxel, were reported to exhibit comparatively higher bioavailability [52-58].

\section{ADVANTAGES OF SNEDDS [59-66]}

- SNEDDS enhance the bioavailability of the drug, thus, reducing dosage frequency

- SNEDDS enable selective drug targeting toward precise absorption window in GI tract

- They possess higher drug payload

- SNEDDS manage controlled drug delivery profile

- SNEDDS are highly stable formulation and uncomplicated manufacture techniques

- SNEDDS facilitate a larger surface interfacial area for drug partitioning among oil and water

- SNEDDS facilitated wider drug distribution in the stomach and GI tract, thus, reducing the irritation caused by extensive contact among drug and gut walls

- SNEDDS protect the drug from the aggressive environment in the GI tract

- SNEDDS improve the rate and extent of absorption.

\section{DISADVANTAGES OF SNEDDS $[67,68]$}

- The conventional dissolution techniques cannot be applied for SNEDDS as they are dependent on digestion former to dissolution

- The in vitro models of SNEDDS need further research and validation for strength evaluation

- The in vitro in vivo correlations of SNEDDS must be studied further

- The chemical instability of drugs

- Higher amounts of surfactant used for formulation (30-60\%)

- Higher production cost

- Lower drug incompatibility and stability

- Possibility of drug leakage and precipitation.

\section{NANO SCIENCE FOR CANCER TREATMENT}

Cancer treatment has observed major advancements in past 30 years due to better understanding of the carcinogenesis process, biology of cancer cells and the tumor micro-environment. The targeted drug delivery has enhanced the prognosis of cancer patients. Most promising way for increasing the survival rate of cancer patients is the use of nanocarriers. Nanoscience is defined by Yang et al. as a "discipline that studies the phenomena and manipulation of materials at atomic, molecular and macromolecular level, where the properties differ significantly from those on a larger scale."

The major drawbacks of systemic chemotherapy include lower drug concentrations in tumor, rapid drug clearance from circulation and toxic side effect on non-cancerous cells. Nanoparticles for anticancer drug delivery comprises nanocarrier and drug, for both nonspecific and specific targeting and delivery, better safety and bioavailability and superior pharmacokinetics.

Nanomaterials size range between 1 and $100 \mathrm{~nm}$ with larger surface area to volume ratios. The nonmaterial ideally used for drug delivery must be non-toxic, biocompatible, blood stable, non-immunogenic, non-thrombogenic, and biodegradable. Tumor-targeted nanodrugs enhance the anti-cancer effects and help in overcoming the toxicity of chemotherapy [69-76]. 
The anti-cancer drug delivery is largely associated with toxicity toward healthy body tissues. The nano transporters used as carriers for anti-cancer drugs enhance the drug therapeutic index, amend the pharmacokinetic profile for improved drug delivery and reduced drug concentration in healthy tissue. The administration of these drugs to tumor sites will overcome the side effect toward healthy tissues and enhance efficiency of the treatment by higher doses of drug to tumor site.

Nanotechnology is a potential delivery system for sparingly soluble antihypertensive agents by enhancing their solubility and bioavailability. These also lead to the progress of novel hydrophobic entities. The biocompatibility, colloidal size, drug targeting, lowered dose size, reduced toxicity, and patient compliance are some important advantages of nanosystems. SNEDDS provide larger interfacial areas for drug partitioning and bioavailability enhancement, which donors need for higher-energy emulsification, in turn, reducing manufacturing cost [77-86].

\section{S-SNEDDS APPLIED FOR ENHANCEMENT OF SOLUBILITY AND BIOAVAILABILITY OF ANTI-CANCER DRUGS}

The current review emphasizes on the model drugs entrectinib and pemigatinib belonging to BCS Class II (low solubility/high permeability), poses a challenge in achievement of optimal dissolution kinetics from the dosage form. Drug release is a crucial and limiting step for oral drug bioavailability, particularly for drugs with low gastrointestinal solubility and high permeability. Hence, formulation into S-SNEDDS might enhance dissolution characteristics of the model drugs by increasing its release and solubility through S-SNEDDS technique.

Entrectinib is an anti-cancer medication used to treat ROS1-positive non-small cell lung cancer and NTRK fusion-positive solid tumors. It is a selective tyrosine kinase inhibitor, of the tropomyosin receptor kinases (TRK) A, B and C, C-ros oncogene 1 (ROS1), and anaplastic lymphoma kinase (ALK) [87-95].

Pemigatinib is a medication for the treatment of adults with previously treated, unresectable locally advanced or metastatic bile duct cancer (cholangiocarcinoma) with a fibroblast growth factor receptor 2 (FGFR2) fusion or other rearrangement as detected by an FDAapproved test. Pemigatinib works by blocking FGFR2 in tumor cells to prevent them from growing and spreading. Pemigatinib belongs to a group of medicines called protein kinase inhibitors. It works by blocking enzymes known as protein kinases; particularly those that are part of receptors (targets) called FGFRs. FGFRs are found on the surface of cancer cells and are involved in the growth and spread of the cancer cells. By blocking the tyrosine kinases in FGFRs, pemigatinib is expected to reduce the growth and spread of the cancer. Both Entrectinib and Pemigatinib are a good choice for the development of SNEDDS formulation for the improvement of solubility and oral bioavailability. Few approved anti-cancer nano-formulations are listed below in Table 1 [96-99].

\section{CONCLUSION AND PERSPECTIVE}

Supersaturable-SEDDSs are a promising approach for the formulation of poorly water-soluble drugs to enhance their bioavailability through the induction and stabilization by PIs of a supersaturated drug state in the GI fluid. This approach overcomes the main limitations associated with conventional solubilized SEDDSs. To use supersaturable-SNEDDS for a target drug, it is important to understand the in-depth mechanism of precipitation through the supersaturation of the drug. From this, it may be possible to inhibit this precipitation and prolong supersaturation by considering the various factors that influence precipitation, based on this mechanism. More insightful understanding of the mechanisms that control the supersaturation and absorption of poorly water-soluble drugs will be achieved by continuing to explore and develop innovatively improved supersaturable-SNEDDS technology, as well as advancing the current characterization and assessment methodologies. This will
Table 1: Overview of approved anti-cancer nanodrugs

\begin{tabular}{|c|c|c|}
\hline Name & Formula & Approved indication (s) \\
\hline DaunoXome & $\begin{array}{l}\text { Liposomal } \\
\text { daunorubicin }\end{array}$ & HIV-related Kaposi sa \\
\hline Caclyx, Doxil & $\begin{array}{l}\text { Pegylated liposomal } \\
\text { doxorubicin }\end{array}$ & $\begin{array}{l}\text { Breast, Ovarian ca, Kaposi } \\
\text { sa, Mulitple myeloma }\end{array}$ \\
\hline DepoCyte & Liposomal cytarabine & Lymphomatousmeningosis \\
\hline Oncaspar & PEG asparaginase & $\begin{array}{l}\text { Acute lymphoblastic } \\
\text { leukemia }\end{array}$ \\
\hline Abraxane & $\begin{array}{l}\text { Albumin-bound } \\
\text { paclitaxel }\end{array}$ & Breast, Pancreas ca, NSCLC \\
\hline Myocet & $\begin{array}{l}\text { Liposomal } \\
\text { doxorubicin }\end{array}$ & $\begin{array}{l}\text { Breast, Ovarian ca, Kaposi } \\
\text { sa, Mulitple myeloma }\end{array}$ \\
\hline Marqibo & Liposomal vincristine & $\begin{array}{l}\text { Acute lymphoblastic } \\
\text { leukemia }\end{array}$ \\
\hline Genexol & $\begin{array}{l}\text { Paclitaxel loaded } \\
\text { polymeric micelle }\end{array}$ & Breast, Pancreas ca, NSCLC \\
\hline Onivyde & Liposomal irinotecan & Pancreas ca \\
\hline Kadcyla & $\begin{array}{l}\text { Trastuzumab linked to } \\
\text { emtansine }\end{array}$ & HER $2+$ breast ca \\
\hline Mepact & $\begin{array}{l}\text { Liposomal } \\
\text { mifamurtide }\end{array}$ & Osteosarcoma \\
\hline Gliadel wafer & $\begin{array}{l}\text { Carmustine in } \\
\text { poliferosan } 20\end{array}$ & $\begin{array}{l}\text { High grade glial tumors- } \\
\text { local therapy }\end{array}$ \\
\hline
\end{tabular}

enhance the therapeutic potential of a wide range of challenging poorly water-soluble drugs that are yet to be discovered. We hope this review will help develop a desired supersaturable-SNEDDS for a model drug.

\section{CONFLICT OF INTEREST}

The authors declare no conflict of interest, financial, or otherwise.

\section{AUTHOR CONTRIBUTIONS}

All authors are contributed equally.

\section{REFERENCES}

1. Haritha B. A review on evaluation of tablets. Formulation Sci Bioavailability 2017;1:1-5.

2. Hetal PT, Jagruti LD. Influence of excipients on drug absorption via modulation of intestinal transporters activity. Asian J Pharm 2015;9:69-82.

3. Kunde SD, Bhilegaonkar SH, Godbole AM, Gajre P. Biopharmaceutical classification system: A brief account. Int J Sci Res Methodol 2015;1:20-46.

4. Benet LZ. The role of BCS (biopharmaceutics classification system) and BDDCS (biopharmaceutics drug disposition classification system) in drug development. J Pharm Sci 2013;102:34-42.

5. Ghadi RR, Dand N. BCS class IV drugs: Highly notorious candidates for formulation development. Drug Deliv Transl Res 2017;248:71-95.

6. Thakare P, Mogal V, Borase P, Dusane J, Kshirsagar S. A review on selfemulsified drug delivery system. J Pharm Biol Eval 2016;3:140-53.

7. Mistry R, Sheth NS. Self-emulsifying drug delivery system. Int J Pharm Pharm Sci 2011;3:23-8.

8. Martin A. Solubility and Distribution Phenomena. $6^{\text {th }}$ ed. Philadelphia, PA: Lippincott Williams and Wilkin; 2011.

9. Fatouros DG, Karpf DM, Nielsen FS, Mullertz A. Clinical studies with oral lipid-based formulations of poorly soluble compounds. Ther Clin Risk Manag 2007;3:591-604

10. Kale AA, Patravale VB. Design and evaluation of self-emulsifying drug delivery systems. (SEDDS) of nimodipine. AAPS PharmSciTech 2008;9:191-6.

11. Kang BK, Lee JS, Chon SK, Jeong SY, Yuk SH, Khang G. Development of self-microemulsifying drug delivery systems. (SMEDDS) for oral bioavailability enhancement of simvastatin in beagle dogs. Int J Pharm 2004;274:65-73.

12. Elgart A, Cherniakov I, Aldouby Y, Domb AJ, Hoffman A. Improved oral bioavailability of BCS class 2 compounds by self-nanoemulsifying drug delivery systems. (SNEDDS): The underlying mechanisms for amiodarone and talinolol. Pharm Res 2013;30:3029-44.

13. Chouksey R, Pandey H, Jain AK, Soni H, Saraogi GK. Preparation 
and evaluation of the self-emulsifying drug delivery system containing atorvastatin HMGCOA inhibiter. Int J Pharm Pharm Sci 2011;3:147-52.

14. Shukla JB, Koli A, Ranch K, Rajesh P. Self-micro emulsifying drug delivery system pharma science monitor. J Pharm Pharm Sci 2010;1:13-33.

15. Shafiq S, Shakeel F, Talegaonkar S. Development and bioavailability assessment of ramiprilnanoemulsion formulation. Eur $\mathrm{J}$ Pharm Biopharm 2007;66:227-43

16. Shakeel F, Iqbal M, Ezzeldin E. Bioavailability enhancement and pharmacokinetic profile of an anticancer drug ibrutinib by self-nanoemulsifying drug delivery system. J Pharm Pharmacol 2016;68:772-80.

17. Chime S, Kenechukwu F, Attama A. Nanoemulsions-advances in formulation, characterization and applications in drug delivery. In: Ali DS, editors. Application of Nanotechnology in Drug Delivery. London: Croatia InTech; 2014. p. 77-111.

18. Khan AW, Kotta S, Ansari SH. Potentials and challenges in self nanoemulsifying drug delivery systems. Exp Opin Drug Deliv 2012;9:1305-17

19. Reddy SM, Reddy MS, Reddy NR, Reddy OM. Formulation and evaluation of novel lipid based solid self-nano emulsifying drug delivery system of repaglinide. Int J Pharm Sci 2014;6:106-10.

20. Singh B, Garg B, Kaur R, Jain A, Kumar R, Katare OP. Selfnanoemulsifying systems for oral bioavailability enhancement. In: Fabrication and Self-Assembly of Nano Biomaterials. Punjab University: William Andrew; 2016. p. 91-115.

21. Pallavi M, Nigade Swapnil L, Patil Shradha S, Tiwari. Self-Emulsifying Drug Delivery System (SEDDS). A Review. IJPBS. 2012;2:42-52.

22. Pouton CW. Lipid formulations for oral administration of drugs nonemulsifying, self-emulsifying and self-micro emulsifying drug delivery systems. Eur J Pharm Sci 2000;11:93-182.

23. Kohli K, Chopra S, Dhar D, Arora S, Khar RK. Self-emulsifying drug delivery systems. An approach to enhance oral bioavailability. Drug Discov Today 2010;15:958-65.

24. Dabros T, Yeung A, Masliyah J, Czarnecki J. Emulsification through area contraction. J Colloid Interface Sci 1999;210:222-4.

25. Sagar SavaleK. A Review-Self Nanoemulsifying Drug Delivery System (SNEDDS). Int J Chem Pharm Rev Res. 2015;4:385-397.

26. Bangia JK, Om H. Nanoemulsions, a versatile drug delivery tool. Int J Pharm Sci Res 2015;6:1363-72.

27. Patel D, Sawant KK. Self-micro-emulsifying drug delivery system: formulation development and biopharmaceutical evaluation of lipophilic drugs. Curr Drug Deliv 2009;6:419-24.

28. Singh B, Bandopadhyay S, Kapil R, Singh R, Katare O. Selfemulsifying drug delivery systems (SEDDS). Formulation development characterization and applications. Crit Rev Ther Drug Carrier Syst 2009;26:427-521.

29. Craig DQ, Barker SA, Banning D, Booth SW. An investigation into the mechanisms of self-emulsification using particle size analysis and low frequency dielectric spectroscopy. Int J Pharm 1995;114:103-10.

30. Nigade PM, Patil S, Tiwari SS. Self-emulsifying drug delivery system (SEDDS): A review. Int J Pharm Biol Sci 2012;2:42-52.

31. Sharma V, Singh J, Gill B, Harikumar SL. SMEDDS: A novel approach for lipophilic drugs. Int J Pharm Sci Res 2012;3:2441-50.

32. Savale KS. A review-self nanoemulsifying drug delivery system (SNEDDS). Int J Chem Pharm Rev Res 2015;4:385-97.

33. Abhishek VG, Salunkhe KS, Chaudhari SR, Gadge PB, Dighe GS, Asati A. A review on, self-micro emulsifying drug delivery system. Am J Pharma Technol Res 2015:5:51-66.

34. Xi J, Chang Q, Chan CK. Formulation development and bioavailability evaluation of a self-nanoemulsified drug delivery system of oleanolic acid. AAPS PharmSci Tech. 2009;10:172-182.

35. Porter CJ, Trevaskis NL, Charman WN. Lipids and lipid-based formulations optimizing the oral delivery of lipophilic drugs. Nat Rev Drug Discov 2007;6:231-48.

36. Harman WN, Porter CJ, Mithani S, Dressman JB. Physicochemical and physiological mechanisms for the effects of food on drug absorption the role of lipids and pH. J Pharm Sci 1997;86:269-82.

37. Shukla Jill B, Akshay RK, Ketan MR, Rajesh KP. Self-micro emulsifying drug delivery system, pharma science monitor. Int J Pharm Sci 2010;1:13-33.

38. Bhargava P, Bhargava S, Daharwal SJ. Self-emulsifying drug delivery system: An approach to improve the solubility of poorly water-soluble drugs. Adv Res Pharm Biol 2011;1:1-9.

39. Porter JH, Pouton CW, Cuine JF, Charman WN. Enhancing intestinal drug solubilization using lipid-based delivery systems. Adv Drug Deliv Rev 2008;60:673-91

40. Kumar A, Sharma S, Kamble R. Self-emulsifying drug delivery system
(SEDDS): Future aspects. Int J Pharm Pharm Sci 2010;2:7-13.

41. Mohsin K, Long MA, Pouton CW. Design of lipid-based formulations for oral administration of poorly water-soluble drugs: Precipitation of drug after dispersion of formulations in aqueous solution. J Pharm Sci 2009;98:3582-95.

42. Do Thi T, Van Speybroeck M, Barillaro V. Formulate-ability of ten compounds with different physicochemical profiles in SMEDDS. Eur J Pharm Sci 2009;38:479-88.

43. Kumar S. Role of nano-emulsion in pharmaceutical sciences-a review. Asian J Res Pharm Sci Biotechnol 2014;2:1-15.

44. Kommuru TR, Gurley B, Khan MA, Reddy IK. Self-emulsifying drug delivery systems (SEDDS) of coenzyme Q10: Formulation development and bioavailability assessment. Int J Pharm 2001;212:233-46.

45. Vonderscher J, Meinzer A. Rationale for the development of sandimmune neoral. Transplant Proc 1994;26:2925-7.

46. Bandyopadhyay S, Katare O, Singh B. Development of optimized supersaturable selfnanoemulsifying systems of ezetimibe: Effect of polymers and efflux transporters. Expert Opin Drug Deliv 2014;11:479-92.

47. Chen Y, Chen C, Zheng J. Development of a solid supersaturatable selfemulsifying drug delivery system of docetaxel with improved dissolution and bioavailability. Biol Pharm Bull 2011;34:278-86.

48. Gao P, Akrami A, Alvarez F. Characterization and optimization of AMG 517 supersaturatable self-emulsifying drug delivery system (S-SEDDS) for improved oral absorption. J Pharm Sci 2009;98:516-28.

49. Thomas N, Holm R, Garmer M. Supersaturated self-nanoemulsifying drug delivery systems (super-SNEDDS) enhance the bioavailability of the poorly water-soluble drug simvastatin in dogs. AAPS J 2013;15:219-27.

50. Kamel AO, Mahmoud AA. Enhancement of human oral bioavailability and in vitro antitumor activity of rosuvastatin via spray dried self nanoemulsifying drug delivery system. J Biomed Nanotechnol 2013;9:26-39

51. Seo YG, Kim DH, Ramasamy T. Development of docetaxel-loaded solid selfnanoemulsifying drug delivery system (SNEDDS) for enhanced chemotherapeutic effect. Int J Pharm 2013;452:412-20.

52. Gao P, Rush BD, Pfund WP, Huang T, Bauer JM, Morozowich W, et al. Development of a supersaturable SEDDS (S-SEDDS) formulation of paclitaxel with improved oral bioavailability. J Pharm Sci 2003;92:2386-98.

53. Poelma FG, Breas R, Tukker JJ, Crommelin DJ. Intestinal absorption of drugs: The influence of mixed micelles on on the disappearance kinetics of drugs from the small intestine of the rat. J Pharm Pharmacol 1991;43:317-24.

54. Gao P, Guyton ME, Huang T, Bauer JM, Stefanski KJ, Lu Q. Enhanced oral bioavailability of a poorly water-soluble drug PNU-91325 by supersaturatable formulations. Drug Dev Ind Pharm 2004;30:221-9.

55. Dahan A, Hoffman A. Rationalizing the selection of oral lipid-based drug delivery systems by an in vitro dynamic lipolysis model for improved oral bioavailability of poorly water-soluble drugs. J Control Release 2008;129:1-10.

56. Morozowich W, Gao P, Charton M. Speeding the development of poorly soluble/poorly permeable drugs by SEDDS/S-SEDDS formulations and prodrugs, Part 1. Am Pharm Rev 2006;9:110-4.

57. Gao P, Charton M, Morozowich W. Speeding the development of poorly soluble/poorly permeable drugs by SEDDS/S-SEDDS formulations and prodrugs, Part 2. Am Pharm Rev 2006;9:16-23.

58. Pellett MA, Davis AF, Hadgraft J. Effect of supersaturation on membrane transport: 2. Piroxicam. Int J Pharm 1994;111:1-6.

59. Malgope A, Murthy PN, Ramani R, Dey S. Development of nanoemulsion as carrier for transdermal delivery of Valsartan. Int $\mathrm{J}$ Pharm Chem Sci 2013;2:1655-65.

60. Sokolov YV. Nanoemulsions as prospective drug delivery systems. News Pharm 2014;1:21-5.

61. Shafiq S, Shakeel F, Talegaonkar S, Azeem A, Ahmad FJ, Khar RK. The nano-emulsion system a review. Eur J Pharm Biopharm 2007;66:227-43.

62. Masoud AM, Baie SH, Arafat OM. The influence of sucrose ester surfactants and different storage condition on the preparation of nanoemulsion. Int J Drug Formulation Res 2012;3:72-87.

63. Mazumder J, Pathak D, Kumria R. Evaluation of antacid activity of microemulsion formulation of blend of essential oil. Int J Pharm Sci Drug Res 2015;7:163-7.

64. Mirza MA, Khan MJ, Iqbal Z. Nanoemulsion technology in unani medicine. Int J Adv Pharm Med Bioallied Sci 2015;3:70-4.

65. Kumar M, Pathak K. Formulation and characterization of nanoemulsionbased drug delivery system of risperidone. Drug Dev Ind Pharm 2009;35:387-95

66. Kanwale NP, Gavali D, Patil D, Bhaskar R, Dhas A, Dwivedi A. Nanoemulsion, a new system for drug delivery. World J Pharm Sci 
2015;4:310-26.

67. Bhosale RR, Osmani RA, Ghodake PP, Shaikh SM, Chavan SR. Nanoemulsion, a review on novel profusion in advanced drug delivery. Indian J Pharm Biol Res 2014;2:122-7.

68. Reddy BA, Debnath MS, Babu MN. Nanoemulsion, a novel approach for lipophilic drugs a review. Asian J Pharm Res 2013;3:84-92.

69. Lu JL, Wang JC, Zhao SX, Liu XY, Zhao H, Zhang X, et al. Selfmicroemulsifying drug delivery system (SMEDDS) improves anticancer effect of oral 9-nitrocamptothecin on human cancer xenografts in nude mice. Eur J Pharm Biopharm 2008;69:899-907.

70. Veltkamp SA, Thijssen B, Garrigue JS, Lambert G, Lallemand F, Binlich $\mathrm{F}$, et al. A novel self-microemulsifying formulation of paclitaxel for oral administration to patients with advanced cancer. Br J Cancer 2006;95:729-34.

71. Hanahan D, Weinberg RA. Hallmarks of Cancer: The next generation. Cell 2011;144:646-74.

72. Hare JI, Lammers T, Ashford MB, Puri S, Storm G, Barry ST. Challenges and strategies in anti-cancer nanomedicine development: An industry perspective. Adv Drug Deliv Rev 2017;108:25-38.

73. Zhang $\mathrm{X}$, Yi Y, Qi J. Controlled release of cyclosporine A selfnanoemulsifying systems from osmotic pump tablets: Near zero-order release and pharmacokinetics in dogs. Int $\mathrm{J}$ Pharm 2013;452:233-40

74. Miao Y, Chen G, Ren L. Characterization and evaluation of selfnanoemulsifying sustained-release pellet formulation of ziprasidone with enhanced bioavailability and no food effect. Drug Deliv 2014;23:110.

75. Park MJ, Balakrishnan P, Yang SG. Polymeric nanocapsules with SEDDS oil-core for the controlled and enhanced oral absorption of cyclosporine. Int J Pharm 2013;441:757-64.

76. Patel VF, Liu F, Brown MB. Advances in oral transmucosal drug delivery. J Control Release 2011;153:106-16.

77. Dünnhaupt S, Kammona O, Waldner C. Nano-carrier systems: Strategies to overcome the mucus gel barrier. Eur J Pharm Biopharm 2015;96:447-53

78. Dimitrov DS. Therapeutic proteins. Methods Mol Biol 2012;899:1-26

79. Sakloetsakun D, Dünnhaupt S, Barthelmes J, Perera G, Schnürch AB. Combining two technologies: Multifunctional polymers and selfnanoemulsifying drug delivery system (SNEDDS) for oral insulin administration. Int J Biol Macromol 2013;61:363-72

80. Karamanidou T, Karidi K, Bourganis V, Kontonikola K, Kammona O, Kiparissides C. Effective incorporation of insulin in mucus permeating self-nanoemulsifying drug delivery systems. Eur J Pharm Biopharm 2015;97:223-9.

81. Qi X, Wang L, Zhu J. Self-double-emulsifying drug delivery system (SDEDDS): A new way for oral delivery of drugs with high solubility and low permeability. Int J Pharm 2011;409:245-51

82. Feeney OM, Williams HD, Pouton CW. 'Stealth'lipid-based formulations: Poly (ethylene glycol)-mediated digestion inhibition improves oral bioavailability of a model poorly water-soluble drug. J Controlled Release 2014;192:219-27.

83. Barthelmes J, Dünnhaupt S, Hombach J. Thiomer nanoparticles: Stabilization via covalent cross-linking. Drug Deliv 2011;18:613-9.

84. Zhao T, Maniglio D, Chen J, Chen B, Motta A, Migliaresi C. Design and optimization of self-nanoemulsifying formulations for lipophilic drugs. Nanotechnology 2015;26:12510.

85. Krishnaiah YS. Pharmaceutical technologies for enhancing oral bioavailability of poorly soluble drugs. J Bioequiv Available 2010;2:28-36

86. Kourentas A, Vertzoni M, Symillides M, Hen B, Brouwers J, Augustijns $\mathrm{P}$, et al. In vitro evaluation of the impact of gastrointestinal transfer on luminal performance of commercially available products of posaconazole and itraconazole using BioGIT. Int J Pharm 2016;515:352-8.

87. Frampton JE. Entrectinib: A review in NTRK+ solid tumours and ROS1+ NSCLC. Drugs 2021;81:697-708.

88. Delgado J, Pean E, Melchiorri D, Migali C, Josephson F, Enzmann H, et al. The European medicines agency review of entrectinib for the treatment of adult or paediatric patients with solid tumours who have a neurotrophic tyrosine receptor kinase gene fusions and adult patients with non-small-cell lung cancer harbouring ROS1 rearrangements. ESMO Open 2021;6:100087.

89. Drilon A, Siena S, Ou SH, Patel M, Ahn MJ, Lee J, et al. Safety and antitumor activity of the multitargeted pan-TRK, ROS1, and ALK inhibitor entrectinib: Combined results from two phase I trials (ALKA372-001 and STARTRK-1) Cancer Discov 2017;7:400-9.

90. Araujo JM, GomezAC, Pinto JA, Rolfo C, Raez LE. Profile of entrectinib in the treatment of ROS1-positive non-small cell lung cancer: Evidence to date. Hematol Oncol Stem Cell Ther 2020;2020:30177.

91. Ardini E, Menichincheri M, Banfi P, Bosotti R, De Ponti C, Pulci R, et al. Entrectinib, a Pan-TRK, ROS1, and ALK inhibitor with activity in multiple molecularly defined cancer indications. Mol Cancer Ther 2016;15:628-39.

92. Liu D, Offin M, Harnicar S, Li BT, Drilon A. Entrectinib: An orally available, selective tyrosine kinase inhibitor for the treatment of NTRK, ROS1, and ALK fusion-positive solid tumors. Ther Clin Risk Manag 2018; $14: 1247-52$.

93. Amboldi N, Pulci R, Texido G, Bosotti R, Magnaghi P, Felder E, et al. Entrectinib, a Pan-TRK, ROS1, and ALK Inhibitor with activity in multiple molecularly defined cancer indications. Mol Cancer Ther 2016;15:628-39

94. Drilon A, Sankhala KK, Liu SV, Cho BC, Blakely C, Chee CE, et al. Abstract CT060: STARTRK-2: A global phase 2, open-label, basket study of entrectinib in patients with locally advanced or metastatic solid tumors harboring TRK, ROS1, or ALK gene fusions. Cancer Res 2017;77:CT060

95. Siena S, Doebele RC, Shaw AT, Karapetis CS, Tan DS, Cho BC, et al. Efficacy of entrectinib in patients (PTS) with solid tumors and central nervous system (CNS) metastases: Integrated analysis from three clinical trials. J Clin Oncol 2019;37:3017.

96. Merz V, Zecchetto C, Melisi D. Pemigatinib, a potent inhibitor of FGFRs for the treatment of cholangiocarcinoma. Future Oncol 2021;17:389-402.

97. Hoy SM. Pemigatinib: First approval. Drugs 2020;80:923-9.

98. Abou-Alfa GK, Sahai V, Hollebecque A, Vaccaro G, Melisi D, AlRajabi $\mathrm{R}$, et al. Pemigatinib for previously treated, locally advanced or metastatic cholangiocarcinoma: A multicentre, open-label, phase 2 study. Lancet Oncol 2020;21:671-84.

99. Romero D. Benefit from pemigatinib in cholangiocarcinoma. Nat Rev Clin Oncol 2020;17:337. 